\title{
Helicobacter pylori virulence genes in the five largest islands of Indonesia
}

\author{
Muhammad Miftahussurur 1,2,3, Ari Fahrial Syam4, Dadang Makmun, Iswan Abbas Nusi², Lukman Hakim Zein ${ }^{5}$, \\ Zulkhairi ${ }^{5}$, Fardah Akil ${ }^{6}$, Willi Brodus Uswan ${ }^{7}$, David Simanjuntak ${ }^{8}$, Tomohisa Uchida ${ }^{9}$, Pangestu Adi ${ }^{3}$, \\ Amanda Pitarini Utari ${ }^{4}$, Yudith Annisa Ayu Rezkitha ${ }^{3}$, Phawinee Subsomwong ${ }^{1}$, Nasronudin ${ }^{3}$ \\ and Yoshio Yamaoka $a^{1,10^{*}}$
}

\begin{abstract}
Background: It remains unclear whether the low incidence of gastric cancer in Indonesia is due to low infection rates only or is also related to low Helicobacter pylori pathogenicity. We collected $\mathrm{H}$. pylori strains from the five largest islands in Indonesia and evaluated genetic virulence factors.

Methods: The genotypes of H. pylori virulence factors were determined by polymerase chain reaction (PCR)-based sequencing. Histological severity of the gastric mucosa was classified into 4 grades, according to the updated Sydney system.
\end{abstract}

Results: A total of 44 strains were analyzed. Forty-three (97.7 \%) were cagA-positive: 26 (60.5\%) were East-Asian-typecagA, 9 (20.9\%) were Western-type-cagA, and 8 (18.6\%) were novel ABB-type, most of which were obtained from Papuan. EPIYT sequences were more prevalent than EPIYA sequences $(P=0.01)$ in the EPIYA-B motif of all types of cagA. The majority of cagA-positive strains $(48.8 \%, 21 / 43)$ had a 6 -bp deletion in the first pre-EPIYA region. Subjects infected with East-Asian-type-cagA strains with a 6-bp deletion had significantly lower inflammation and atrophy scores in the corpus than those infected with Western-type-cagA strains (both $P=0.02$ ). In total, $70.4 \%$ of strains possessed the vacA s $1 \mathrm{~m} 1$ genotype and $29.5 \%$ were $\mathrm{m} 2$. All strains from peptic ulcer patients were of the iceA1 genotype, which occurred at a significantly higher proportion in peptic ulcer patients than that in gastritis patients $(55.3 \%, \mathrm{P}=0.04)$. The double positive genotype of jhp0562/ $\beta$-(1,3)galT was predominant $(28 / 44,63.6 \%)$, and subjects infected with this type had significantly higher inflammation scores in the corpus than those with the jhp0562 negative/ $\beta$ - $(1,3)$ galT positive genotype (mean [median]; 1.43 [1] vs. 0.83 [1], $P=0.04$ ). There were significant differences in cagA and pre-EPIYA cagA type, oipA status, and jhp0562/ $\beta$ - $(1,3)$ galT type among different ethnic groups $(P<0.05)$.

Conclusions: In addition to a low H. pylori infection rate, the low incidence of gastric cancer in Indonesia might be attributed to less virulent genotypes in predominant strains, which are characterized by the East-Asian-type-cagA with a 6 -bp deletion and EPIYT motif, a high proportion of $\mathrm{m} 2$, dupA negative or short type dupA, and the jhp0562/ $\beta$ - $(1,3)$ galT double positive genotype.

Keywords: Helicobacter pylori, Indonesia, Virulence factors

\section{Background}

Helicobacter pylori infection remains latent in the majority of infected patients, and only a minority of individuals

\footnotetext{
*Correspondence: yyamaoka@oita-u.ac.jp; yyamaoka@bcm.edu

${ }^{10}$ Department of Gastroenterology and Hepatology, Baylor College of Medicine and Michael DeBakey Veterans Affairs Medical Center, Houston, TX 77030, USA

Full list of author information is available at the end of the article
}

with $H$. pylori infection ever develop severe disease [1]. Moreover, the differences in $H$. pylori infection rates cannot adequately explain differences in the incidence of gastric cancer in the world. Therefore, in addition to host and environmental factors, differences in the incidence of gastric cancer irrespective of $H$. pylori infection rate can be explained by differences in virulence factors [2]. Several genes have been proposed as possible virulence 
determinants: $\operatorname{cag} A, \operatorname{vac} A, \operatorname{oip} A$, iceA, $\operatorname{dup} A, j h p 0562$, and $\beta-(1,3) \operatorname{galT}[2,3]$.

$\operatorname{cag} A$ is the major $H$. pylori virulence factor. The sequence of the second repeat region was found to differ considerably between East-Asian-type-cagA and Westerntype-cagA. Each CagA is assigned to a sequence type consisting of the names of the EPIYA segments in its sequence (that is, $\mathrm{ABC}, \mathrm{ABCC}$, or $\mathrm{ABCCC}$ for Western-type- and $\mathrm{ABD}$ for East-Asian-type-cagA). East-Asian-type-cagA has a higher binding affinity for the Src homology-2 domaincontaining phosphatase 2 (SHP2), resulting in a higher risk of peptic ulcer and/or gastric cancer than Western-typecagA [4-7]. The pre-EPIYA region of cagA, located about 300-bp upstream of the first EPIYA motif, has also been investigated. Alignment of these sequences revealed that a 39-bp deletion was present in most strains isolated from East Asia, but was absent in most strains from Western countries (no deletion) [8].

$v a c A$, the second major $H$. pylori virulence factor, produces variations in the vacuolating activity of $H$. pylori strains. In general, the $v a c A \operatorname{sim} 1$ strain produces a large amount of toxin with high vacuolating activity in gastric epithelial cells, while the s1m2 strain produces moderate amounts of toxin, and the $\mathrm{s} 2 \mathrm{~m} 2$ strain produces low or undetectable amounts of toxin [9]. cagA status is linked to the $v a c A$ s region type, and it is further closely linked to the presence of the oip $A$ "on" status, which is a virulence factor coding an outer membrane protein $[10,11]$. Previous studies demonstrated that almost all $H$. pylori strains circulating in Japan were extremely virulent, irrespective of clinical outcomes, and harbored the following genotype: East-Asiantype-cagA, vacA s1, and the oipA "on" status [11, 12].

An initial series of studies showed that ice $A$ has 2 main allelic variants: ice $A 1$ and ice $A 2$ [10, 13]. The expression of ice $A 1$ was upregulated on contact between $H$. pylori and human epithelial cells, and the iceA1 genotype was associated with enhanced mucosal interleukin (IL)-8 expression and acute antral inflammation [13, 14]. $\operatorname{dup} A$, the first genetic factor of $H$. pylori to be characterized, was reported to be associated with a differential susceptibility to duodenal ulcer (DU) and gastric cancer [15]. Additionally, a number of recent studies have indicated that jhp0562 and $\beta-(1,3)$ galT were associated with the development of peptic ulcers $[3,16]$. Our previous study indicated that in the US population, the absence of $\beta$ - $(1,3)$ galT was an independent factor for differentiating DU and gastric ulcer (GU) from gastritis [10]. Together with other virulence factors, jhp0562 and $\beta$-(1,3)galT might be predictors of severe clinical outcomes of $H$. pylori infection, as well as of gastric cancer.

Indonesia is a country in Southeast Asia with low risk of gastric cancer; it is an archipelago with a multi-ethnic society. The age-standardized incidence of gastric cancer in Indonesia was reported to be $2.8 / 100,000$, which is relatively low among Asian countries (available from the International Agency for Research on Cancer; GLOBOCAN2012, http://globocan.iarc.fr/). In March 2013, there were only 313 hospitals providing GI endoscopy services in Indonesia, and most of them were located on the island of Java [17]. Moreover, many patients with dyspepsia are not covered by the Indonesian health insurance system; therefore, it is difficult for them to undergo endoscopy. Our previous study using 5 different diagnostic methods confirmed that the prevalence of $H$. pylori infection in Surabaya (Java island) was low (only $11.5 \%$ ) [18]. We also found a low prevalence of $H$. pylori infection in a minor group of North Sulawesi; the prevalence was only $14.3 \%$ for adults and $3.8 \%$ for children [19]. However, it remains unclear whether the low incidence of gastric cancer in Indonesia is due to low infection rates only or also owing to low $H$. pylori pathogenicity. In this study, we collected $H$. pylori strains from the five largest islands in Indonesia and evaluated genetic virulence factors.

\section{Results \\ Patients and $H$. pylori}

From January 2014 to June 2015, we recruited a total 311 patients with dyspeptic symptoms (170 female and 141 male; mean age of $47.8 \pm 14.6$ years; range, $17-80$ years) from several ethnicities in the 5 largest islands in Indonesia, including Jakarta and Surabaya (Java island), Jayapura (Papua island), Makassar (Sulawesi island), Pontianak (Borneo island), and Medan (Sumatera island). Among 311 patients, 180 (57.9\%) showed no gastric activity, inflammation, or atrophy, neither in the antrum nor in the corpus, by histological examination; these patients were considered to be the normal group. All subjects in the normal group were negative for $H$. pylori infection. Among the remaining 131 patients with some histological changes (activity, inflammation and/or atrophy), 44 (33.6\%) were positive for $H$. pylori.

Even though we obtained a large number of samples, only 39 strains could be isolated. We therefore decided to add 5 strains isolated in Surabaya (Java island) with corresponding histological information that had already been evaluated by the same pathologist (UT). These were isolated from patients with the following ethnicities: Javanese $(\mathrm{n}=1)$, Floresnese $(\mathrm{n}=2)$, and Chinese Indonesian $(n=2)$ [18]. Overall, a total of 44 strains (38 from patients with gastritis, 5 with GU, and 1 with DU) were included in the final analysis. Twenty-four strains were isolated from males (age range, 25-77 years; mean age, 49.4 years) and 20 from females (age range, 26-67 years; mean age, 47.4 years). The strains were from patients with the following ethnicities: 16 Batak, 9 Papuans, 5 Buginese, 7 Chinese Indonesian, 3 Floresnese, 2 Javanese, 
and 2 Dayak. Although the number of samples was not sufficient for statistically significant conclusions, we found that the Buginese, Dayak, and Papuan had a tendency toward higher inflammation in the antrum than the Floresnese (mean [median]: 2.00 [2], 2.5 [2.5], 2.0 $[2.0]$ vs. $1.0[1], \mathrm{P}=0.05)$.

\section{Virulence genes of Indonesian strains and histology}

In total, 43 of 44 strains possessed the cagA gene $(97.7 \%)$. Sequence analyses revealed that 23 strains were of the ABD type and 3 were of the AABD type, which were both considered East-Asian-type-cagA (26/43, $60.5 \%)$. Western-type-cagA (ABC, ABCC, BC, B) was found in $20.9 \%$ $(9 / 43)$ of isolates. One strain with $B$ type was regarded as Western-type-cagA based on the sequence similarity of B-segments with Western-type-cagA. Interestingly, 8 strains had ABB type (18.6\%), which is very rare in other countries. Sequences of both B segments in the ABB type were different from those of East-Asian-type- or Western-type-cagA (Fig. 1). Therefore, we classified the ABB type as an independent group.

Sequence analyses of the $300 \mathrm{bp}$ upstream of the first EPIYA motif (EPIYA-A) revealed that the predominant pre-EPIYA type contained a 6-bp deletion (48.8 \%, 21/43), which is also very rare in other countries (Table 1). Eleven (25.6\%) strains contained an 18-bp deletion, which is typically observed in Vietnamese strains [8], and 3 strains contained a 39-bp deletion typically observed in East Asian countries. The remaining 8 strains contained no deletion, which is typically observed in Western countries. Only 1 Western-type-cagA was not classified as containing no deletion. For East-Asian-type-cagA strains, the predominant pre-EPIYA type contained a 6-bp deletion $(80.8 \%, 21 / 26)$. All ABB types contained an 18-bp deletion (Table 1).
Histological analysis showed that inflammation and atrophy scores in the corpus were significantly higher in subjects infected with Western-type-cagA strains than those with East-Asian-type-cagA strains (mean [median]; 1.88 [1] vs. 1.23 [1], $\mathrm{P}=0.03$ and 1.00 [1] vs. 0.42 [0], $\mathrm{P}=0.04$, respectively) (Table 2 ), a result that opposes the current consensus. However when analyzed in detail, only subjects infected with strains possessing East-Asiantype-cagA containing the 6-bp deletion had significantly lower inflammation and atrophy scores in the corpus than those possessing Western-type-cagA (1.88 [1] vs. $1.19[1], \mathrm{P}=0.02$ and $1.00[1]$ vs. $0.33[0], \mathrm{P}=0.02$, respectively) (Table 2 ). There were no significant differences in inflammation between subjects infected with strains possessing East-Asian-type-cagA containing the 18- or 39-bp deletions, or the ABB type with Westerntype-cagA (all $\mathrm{P}>0.05$ ).

The EPIYA motifs in these strains were also evaluated (Table 3). We obtained five types of EPIYA or EPIYAlike sequences. In total, 127 EPIYA motifs were obtained from the 43 CagAs. The 2 most common 5 amino acid EPIYA motifs were EPIYA (89/127, $70.1 \%$ ) and EPIYT (25.2\%), in agreement with our previous studies [20, 21]. The EPIYA-B motif displayed the biggest change in five amino acids, and EPIYT was more prevalent than EPIYA in all types of CagA (Table 3), not only in Western-type$\operatorname{cag} A$, which was reported previously $[20,21]$. When we analyzed the first EPIYA-B motif, we found that subjects infected with strains with EPIYT sequences had higher inflammation in the antrum than those with EPIYA sequences $(2.03$ [2] vs. $1.27[1], \mathrm{P}=0.01)$. Further, when we analyzed the first EPIYA-B motif only in East-Asiantype-cagA, we found that subjects infected with strains with EPIYT sequences had higher activity in the antrum than those with EPIYA sequences (1.35 [1] vs. 0.5 [0.5],

\begin{tabular}{|c|c|c|}
\hline & EPIYA-A & EPIYA-B \\
\hline WT-type-cagA consensus & EP I Y AQVNKKKTGQVA & SPEEP | YAQVAKKVNAK|DRLNQ | ASGLGGVGQAAG \\
\hline \multirow[t]{2}{*}{$\begin{array}{l}\text { EA-type-cagA consensus } \\
\text { ABB type } \operatorname{cag} A \text { (Jay } 1)\end{array}$} & $\begin{array}{l}\text { EP I YAKVNKKKAGQAT } \\
\text { EP I YAQVNKKKAGQAA } \\
*_{* * * * * * * * * * *}\end{array}$ & 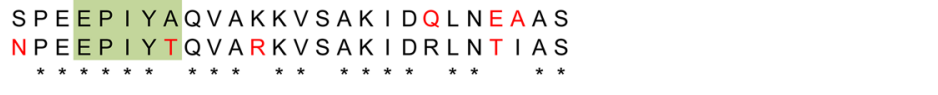 \\
\hline & & EPIYA-C \\
\hline \multirow[t]{2}{*}{ WT-type-cagA consensus } & FPLKRHDK & VDDLSKVGLSASPEP I YAT I DDLGGP - - FPLKRHDKVDDLSKVG \\
\hline & & EPIYA-D \\
\hline \multirow[t]{2}{*}{ EA-type-cagA consensus } & A INRKIDRINKIASAGKG & VGGFSGAGRSASPEP I YAT I DFDEANQAG FPLRRSAAVNDLSKVG \\
\hline & & EPIYA-B \\
\hline ABB type $\operatorname{cag} A($ Jay 1$)$ & A I NAK I SQLNEANQAA - - & 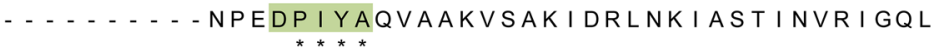 \\
\hline \multicolumn{3}{|c|}{$\begin{array}{l}\text { Fig. } 1 \text { Sequence analysis of CagA structural polymorphisms in Indonesian strains. Eight strains had ABB type; most were Papuan, which was very } \\
\text { rare in other countries. Sequences of the first and second segment B in the ABB type were similar to segment B in East-Asian-type-cagA; however, } \\
\text { the second segment B contained a trace of the segment D component of East-Asian-type-cagA. The star symbol indicates the sequence similarities } \\
\text { among all cagA types. In contrast, the red color emphasizes sequence differences }\end{array}$} \\
\hline
\end{tabular}


$\mathrm{P}=0.03)$. There were no significant differences in histological scores for EPIYT motifs in the ABB type and East-Asian-type-cagA.

The predominant genotype for $v a c A$ was s1 (43/44, $97.7 \%$ ), whereas the $v a c A \mathrm{~m} 2$ genotype was found in $29.5 \%(13 / 44)$, and the vacA s2 genotype was found in only $2.3 \%(1 / 44)$ of isolates. For the combined vacA $\mathrm{s}$ and $\mathrm{m}$ regions, the $\mathrm{s} 1 \mathrm{~m} 1, \mathrm{~s} 1 \mathrm{~m} 2$, and $\mathrm{s} 2 \mathrm{~m} 2$ were found in $70.4 \%(31 / 44), 27.3 \%(12 / 44)$, and $2.3 \%(1 / 44)$ of isolates, respectively.

The iceA1 genotype was predominant $(61.4 \%, 27 / 44)$, and $36.4 \%$ of isolates were of the ice $A 2$ genotype (16/44). The remaining 1 isolate was positive for both iceA 1 and iceA2 (iceA1/iceA2 mixed). Interestingly, all strains from peptic ulcer patients $(\mathrm{n}=6)$ were of the iceA1 type; the iceA1 type occurred more frequently in peptic ulcer patients than in gastritis patients $(55.3 \%(21 / 38)$, $\mathrm{P}=0.04)$.

The oipA "on" status was predominant in Indonesian strains (40/44, $90.9 \%$ ), and the remaining strains were considered "off." All peptic ulcer patients were dupA negative. Only $3(6.8 \%)$ strains were $\operatorname{dup} A$ positive (all were from gastritis patients) and none of them were the intact long-type $\operatorname{dup} A$, a strong $\operatorname{dupA}$ virulence marker for severe outcomes [22]. There were no significant differences between $v a c A$, iceA, oipA, and $\operatorname{dup} A$ status with gastric mucosal status (all $\mathrm{P}>0.05$ ).

The jhp0562/ $\beta$ - $(1,3) g a l T$ double positive was the predominant type $(28 / 44,63.6 \%)$, followed by jhp0562 positive/ $\beta$-(1,3)galT negative, and jhp0562 negative/ $\beta$ - $(1,3)$ galT positive $(10 / 44(22.7 \%)$ and $6 / 44$ (13.6\%), respectively). Histological analysis showed that inflammation scores in the corpus were significantly higher in subjects infected with strains containing the jhp0562/ $\beta$-(1,3)galT double positive genotype than in those with $j$ hp0562 negative/ $\beta$ - $(1,3)$ galT positive [mean (median); 1.43 (1) vs. 0.83 (1), $\mathrm{P}=0.04$ ], but not significantly different from those with $j h p 0562$ positive/ $\beta$ - $(1,3)$ galT negative $(\mathrm{P}=0.47)$.

\section{Virulence genes and ethnics groups}

The association between virulence genes and ethnicity is shown in Table 4 . There were significant differences among ethnic groups with respect to cagA type, pre-EPIYA cagA type, oipA status, and jhp0562/ $\beta-(1,3)$ galT type $(\mathrm{P}<0.001, \mathrm{P}=0.004, \mathrm{P}=0.03$, and $\mathrm{P}=0.05$,

Table 1 Association between cagA type and pre-EPIYA cagA type

\begin{tabular}{|c|c|c|c|c|c|}
\hline \multirow[t]{2}{*}{ cagA type } & \multirow[t]{2}{*}{ n } & \multicolumn{4}{|c|}{ Pre-EPIYA cagA type } \\
\hline & & 6-bp deletion & 18-bp deletion & 39-bp deletion & No deletion \\
\hline East-Asian-type-cagA & 26 & $21(80.8 \%)$ & $2(7.6 \%)$ & $3(11.5 \%)$ & $0(0.0 \%)$ \\
\hline Western-type-cagA & 9 & $0(0.0 \%)$ & $1(11.1 \%)$ & $0(0.0 \%)$ & $8(88.9 \%)$ \\
\hline ABB type & 8 & $0(0.0 \%)$ & $8(100.0 \%)$ & $0(0.0 \%)$ & $0(0.0 \%)$ \\
\hline Total & 43 & $21(48.8 \%)$ & $11(25.6 \%)$ & $3(7.0 \%)$ & $8(18.6 \%)$ \\
\hline
\end{tabular}

Table 2 Histological scores according to cagA type and pre-EPIYA cagA type

\begin{tabular}{|c|c|c|c|c|c|}
\hline & \multirow[t]{2}{*}{ Western-type-cagA } & \multicolumn{3}{|c|}{ East-Asian-type-cagA } & \multirow[t]{2}{*}{ ABB type } \\
\hline & & All & 6-bp deletion & No 6-bp deletion & \\
\hline$n$ & 9 & 26 & 21 & 5 & 8 \\
\hline \multicolumn{6}{|l|}{ Antrum } \\
\hline Activity & $1.63(1.5)$ & $1.15(1)$ & $1.19(1)$ & $1.50(1.5)$ & $1.63(1.5)$ \\
\hline Inflammation & $1.88(2)$ & $1.73(2)$ & $1.76(2)$ & $1.60(1)$ & $2.00(2)$ \\
\hline Atrophy & $1.25(1)$ & $1.04(1)$ & $1.05(1)$ & $1.00(1)$ & $1.13(1)$ \\
\hline Intestinal metaplasia & $0.13(0)$ & $0.00(0)$ & $0.00(0)$ & $0.00(0)$ & $0.00(0)$ \\
\hline \multicolumn{6}{|l|}{ Corpus } \\
\hline Activity & $0.88(1)$ & $0.77(0)$ & $0.76(1)$ & $0.80(1)$ & $0.75(1)$ \\
\hline Inflammation & $1.88(2)$ & $1.23(1)^{*}$ & $1.19(1)^{*}$ & $1.40(1)$ & $1.63(2)$ \\
\hline Atrophy & $1.00(1)$ & $0.42(0)^{*}$ & $0.33(0)^{*}$ & $0.80(1)$ & $0.88(1)$ \\
\hline Intestinal metaplasia & $0.25(0)$ & $0.00(0)$ & $0.00(0)$ & $0.00(0)$ & $0.00(0)$ \\
\hline
\end{tabular}

Histology data are presented as mean (median)

* $\mathrm{P}<0.05$ compared to Western-type-cagA 
Table 3 Frequencies of EPIYA motifs in Indonesia strains

\begin{tabular}{|c|c|c|c|c|c|c|c|c|}
\hline Type & All motifs & No. & A motif & No & B motif & No & Cor D motif & No \\
\hline & EPIYA & 89 & EPIYA & 44 & EPIYA & 11 & EPIYA & 34 \\
\hline & EPIYT & 32 & & & EPIYT & 32 & & \\
\hline & DPIYA & 1 & & & DPIYA & 1 & & \\
\hline & DPIYT & 4 & & & DPIYT & 4 & & \\
\hline & EPVYT & 1 & & & EPVYT & 1 & & \\
\hline Total & & 127 & & & & & & \\
\hline \multirow[t]{2}{*}{ ABD-type cagA } & EPIYA & 62 & EPIYA & 29 & EPIYA & 7 & EPIYA & 26 \\
\hline & EPIYT & 19 & & & EPIYT & 19 & & \\
\hline Total & & 81 & & & & & & \\
\hline \multirow[t]{3}{*}{ ABC-type cagA } & EPIYA & 18 & EPIYA & 7 & EPIYA & 3 & EPIYA & 8 \\
\hline & EPIYT & 5 & & & EPIYT & 5 & & \\
\hline & EPVYT & 1 & & & EPVYT & 1 & & \\
\hline Total & & 24 & & & & & & \\
\hline \multirow[t]{4}{*}{ ABB-type cagA } & EPIYA & 9 & EPIYA & 8 & EPIYA & 1 & EPIYA & 0 \\
\hline & EPIYT & 8 & & & EPIYT & 8 & & \\
\hline & DPIYT & 4 & & & DPIYT & 4 & & \\
\hline & DPIYA & 1 & & & DPIYA & 1 & & \\
\hline Total & & 22 & & & & & & \\
\hline
\end{tabular}

respectively). The ABB type was predominant in Papuan strains, and all strains contained the 18-bp deletion. Papuan strains had a low prevalence of the double positive jhp0562/ $\beta-(1,3)$ galT type. Although all Batak's $H$. pylori were ABD-type oipA "on" status, all of the strains contained the 6-bp deletion. Buginese and Dayak ethnicities typically had Western type cagA with oipA "on" status and no deletion in pre-EPIYA cagA. The Batak, Buginese, Chinese, and Floresnese had a higher prevalence of $v a c A$ $m 2$ than the Papuan and Javanese. The Chinese and Floresnese $H$. pylori had a lower prevalence of the iceA1 genotype than the other ethnicities.

\section{Nucleotide sequencing}

The cagA sequencing data for the 38 strains that were cagA positive are available under DDBJ accession numbers LC062626 to LC062663. The oipA sequencing data of the 39 Indonesian strains are available under DDBJ accession numbers LC062664 to LC062702.

\section{Discussion}

This study complements the results of a previous report [18], in which virulence factors from $5 \mathrm{H}$. pylori strains collected from 1 city in Java island were characterized. Although a small study, this is the first study to characterize the relationship between $H$. pylori virulence factors, ethnicity, and the severity of histological scores. We found that in Indonesian strains, the cagA type was predominantly East Asian-type-cagA. In comparison to individuals with Western-type-cagA strains containing
EPIYA-C segments, those infected with East-Asian-typecagA strains containing EPIYA-D segments reported an increased risk of peptic ulcer or gastric cancer [23, 24]. However, surprisingly, we showed that subjects infected with Western-type-cagA strains produced more clinical evidence of virulence than those with East-Asian-typecagA. This unusual result could be explained partly by the fact that most East-Asian-type-cagA strains contained the pre-EPIYA 6-bp deletion, but not the typical 39-bp deletion. In fact, our data showed that only subjects infected with strains possessing the ABD type-cagA containing the 6-bp deletion had significantly lower inflammation and atrophy scores in the corpus than those possessing Western-type-cagA. Our previous study showed that preEPIYA types appear to be specific for geographic region. No deletion type was predominant in Western countries and the 39-bp deletion type was present in most strains isolated from East Asia. Many Vietnamese strains (75 \%) contained the 18-bp deletion, which was rare in other Asian countries [8]. Indonesian strains could not be distinguished from other East Asian strains on the basis of previous genotyping, including the cagA repeat region genotypes. Therefore, a unique 6-bp deletion type could be applicable as a new genetic marker for the genomic diversity of $H$. pylori and as a new marker for Indonesian H. pylori strains. Indonesia has a lower risk of gastric cancer than Vietnam and East Asian countries such as Japan and South Korea, suggesting that the pre-EPIYA region might have some biological functions that partly contribute to the differences in the incidence of gastric 
Table 4 Association between virulence genes and ethnic groups

\begin{tabular}{|c|c|c|c|c|c|c|c|}
\hline Virulence genes & Papuan & Batak & Buginese & Javanese & Chinese & Dayak & Floresnese \\
\hline Number of strain & 9 & 16 & 5 & 2 & 7 & 2 & 3 \\
\hline cagA positive & $100 \%$ & $100 \%$ & $100 \%$ & $100 \%$ & $100 \%$ & $100 \%$ & $66.7 \%$ \\
\hline \multicolumn{8}{|l|}{ cagA type* } \\
\hline East-Asian-type-cagA & $11.1 \%$ & $100.0 \%$ & $40.0 \%$ & $0.0 \%$ & $71.4 \%$ & $0.0 \%$ & $100.0 \%$ \\
\hline Western-type-cagA & $11.1 \%$ & $0.0 \%$ & $60.0 \%$ & $50.0 \%$ & $28.6 \%$ & $100.0 \%$ & $0.0 \%$ \\
\hline ABB type & $77.8 \%$ & $0.0 \%$ & $0.0 \%$ & $50.0 \%$ & $0.0 \%$ & $0.0 \%$ & $0.0 \%$ \\
\hline Predominant pre-EPIYA cagA type (\%)* & $\begin{array}{l}\text { 18-bp deletion } \\
\text { (88.9\%) }\end{array}$ & $\begin{array}{l}\text { 6-bp deletion } \\
\quad(100.0 \%)\end{array}$ & $\begin{array}{l}\text { No deletion } \\
(60.0 \%)\end{array}$ & $\begin{array}{l}\text { No deletion } \\
\text { (50.0\%) }\end{array}$ & $\begin{array}{l}\text { 39-bp deletion } \\
(28.6 \%)\end{array}$ & $\begin{array}{l}\text { No deletion } \\
(100.0 \%)\end{array}$ & $\begin{array}{l}\text { 18-bp deletion } \\
(50.0 \%)\end{array}$ \\
\hline $\operatorname{vacA} \mathrm{m} 2(\%)^{*}$ & $0.0 \%$ & $37.5 \%$ & $40.0 \%$ & $0.0 \%$ & $42.9 \%$ & $0.0 \%$ & $66.7 \%$ \\
\hline iceA1 genotype (\%) & $88.9 \%$ & $62.5 \%$ & $60.0 \%$ & $50.0 \%$ & $42.9 \%$ & $50.0 \%$ & $33.3 \%$ \\
\hline Double positive jhp0562/ $\beta$-(1,3)galT (\%)* & $33.3 \%$ & $87.5 \%$ & $40.0 \%$ & $50.0 \%$ & $71.4 \%$ & $50.0 \%$ & $66.7 \%$ \\
\hline oipA "on" (\%)* & $77.8 \%$ & $100.0 \%$ & $100.0 \%$ & $100.0 \%$ & $100.0 \%$ & $50.0 \%$ & $66.7 \%$ \\
\hline dupA negative (\%) & $100.0 \%$ & $100.0 \%$ & $100.0 \%$ & $100.0 \%$ & $85.7 \%$ & $100.0 \%$ & $33.3 \%$ \\
\hline
\end{tabular}

* $\mathrm{P}<0.05$

cancer. Further studies will be necessary to investigate the function of the pre-EPIYA region.

There were interesting associations between genotype and ethnicity. The ABB type was predominant in Papuan strains and all strains contained the 18-bp deletion. Papuans are various indigenous peoples of Papua Island and neighboring islands [25]. This ABB type was similar to strain PNGhigh85, which was isolated in Papua (New Guinea) and was classified as hpSahul type by multilocus sequence typing using seven housekeeping genes [26]. Further studies with a larger sample size are necessary to clarify the association between $H$. pylori genotype and the ethnic groups in Indonesia.

The predominant amino acid sequence of the EPIYA$B$ motif in the cagA genes of Indonesian strains was EPIYT, not EPIYA, for all types of cagA. Previous studies reported that EPIYT was the second most common sequence in the EPIYA-B motif of Western-type cagA, but was very rare in East-Asian-type-cagA [20, 21, 27]. Zhang et al. analyzed 364 Western-type-cagA and reported that gastric cancer was associated with the EPIYA sequence in the EPIYA-B motif, whereas the EPIYT sequence was associated with DU [27]. We found that subjects infected with strains with EPIYT sequences had higher activity and inflammation scores in the antrum than those with EPIYA sequences, which is consistent with the association between EPIYT sequences and DU. Antral gastritis induces hyperacidity, which might predispose patients to gastric metaplasia of the duodenal mucosa, which would allow H. pylori colonization of the duodenum and further propagate duodenal ulceration [1]. Unfortunately, in the present study we obtained only one patient with DU and could not confirm their results. Contrary to GU, DU has a paradoxical relationship with gastric cancer [28, 29]. Indonesian strains also had a high proportion of the m2 genotype, which was similar to other countries with a low incidence of gastric cancer such as Thailand [30] and Bangladesh [31]. Therefore, the different genotypes of Indonesian $H$. pylori could explain, at least in part, the low incidence gastric cancer in Indonesia. Although gastric carcinogenesis might be influenced by the virulence factors, the host's genetic and environmental factors also play a role in determining the risk of gastric cancer.

Although the Le antigenic structures were reported to be important for bacterial colonization, adhesion, and evasion of host immune response [32, 33], the role of these in $H$. pylori infection has not been elucidated. Oleastro et al. found the presence of $j h p 0562$ alone (jhp0562-positive/ $\beta$-(1,3)galT-negative) was associated with peptic ulcers, rather than with gastritis, and the presence of $\beta$-(1,3)galT alone (jhp0562-negative/ $\beta-(1,3)$ galT-positive) was associated with gastritis, rather than with peptic ulcers [16]. Our previous study revealed that the prevalence of the jhp0562 and $\beta-(1,3) g a l T$ double positive was significantly higher in strains from the US than in strains from Japan [3]. Moreover, the double positive type was significantly less prevalent in strains from peptic ulcer patients than in those from gastritis patients [3]. The US population has a lower risk of gastric cancer than the Japanese population. Therefore, the predominant double genotypes in Indonesia might be related to the less virulent $H$. pylori strains. Additional in vitro and in vivo studies are necessary to investigate the mechanisms by which these gene products correlate with clinical outcomes. Because these two genes were inversely correlated, the products of the two genes may have the same cell function, thus producing functional redundancy.

Interestingly, only three strains studied were $d u p A$ positive and there were no intact long-type $d u p A$. Schmidt 
et al. reported there was significant variability in the prevalence of $d u p A$ among geographical locations, and also among ethnic groups resident in the same country. Indian Malaysia had a low prevalence of $\operatorname{dup} A$, which was only $7.1 \%$, which was lower than in isolates from the Chinese (28.9\%) and the Malay in Malaysia (35.7 \%) [34]. It is still unclear why $H$. pylori from some ethnicities lack $d u p A$. We previously reported that the intact long-type $\operatorname{dupA}$ without frameshift mutation, but not the shorttype $\operatorname{dup} A$, was associated with GU and gastric cancer, but not gastritis, in an Okinawa population in Japan [22]. Therefore, the lack of the $\operatorname{dupA}$ gene, especially the intact long-type $\operatorname{dup} A$, might partly explain the low incidence of gastric cancer in Indonesia.

Our meta-analysis [35] showed that the presence of iceA1 was associated with peptic ulcer, but not gastric cancer (odds ratio $[\mathrm{OR}]=1.25,95 \% \mathrm{CI}=1.08-1.44$ ), and that the presence of iceA2 was inversely associated with peptic ulcer $(\mathrm{OR}=0.76,95 \% \mathrm{CI}=0.65-0.89)$. In this study, we also found a significant association between iceA1 genotypes and peptic ulcer. However, $\operatorname{cagA}[2]$ and the usage of non-steroidal anti-inflammatory drugs are also important factors for the development of peptic ulcers [36]. To confirm the significance of ice $A$, it is better to perform a multivariate analysis adjusted for the $\operatorname{cag} A$ status and other risk factors for peptic ulcer. Unfortunately, the number of strains was not sufficient for multivariate analysis. Further studies will be necessary to investigate the association between
H. pylori virulence factors and peptic ulcers and gastric cancer in Indonesia.

\section{Conclusions}

Although there are many issues to be confirmed, in addition to low $H$. pylori infection rates, the low incidence of gastric cancer in Indonesia might be attributed to less virulent genotypes of the predominant strains. In general, $\operatorname{cagA}$ positive (especially East-Asian-type $\operatorname{cag} A$ containing a 39-bp deletion), vacA $\mathrm{s} 1 \mathrm{~m} 1$, oipA “on", ice $A 1$ positive, $j h p 0562$-positive $/ \beta$ - $(1,3)$ galT-negative, and intact long-type $\operatorname{dupA}$ positive are considered to be virulent genotypes [37]. In contrast, we found that the predominant genotypes in Indonesian strains included EastAsian-type-cagA containing a 6-bp deletion, m2, dupA negative/short type $\operatorname{dup} A$, and the $j h p 0562 / \beta-(1,3)$ galT double positive genotypes (Fig. 2).

\section{Methods}

Gastric biopsy specimens were taken from the antrum (pyloric gland area) and the corpus (fundic gland area). Biopsy specimens for culture were immediately placed at $-20{ }^{\circ} \mathrm{C}$ and stored at $-80{ }^{\circ} \mathrm{C}$ within a day of collection until they were used for culture testing. Two antral specimens were used for $H$. pylori culture and histological examination. One corporal specimen was used for histological examination. Patients were considered to be negative for $H$. pylori infection when culture and histology results were negative, whereas patients with at least one

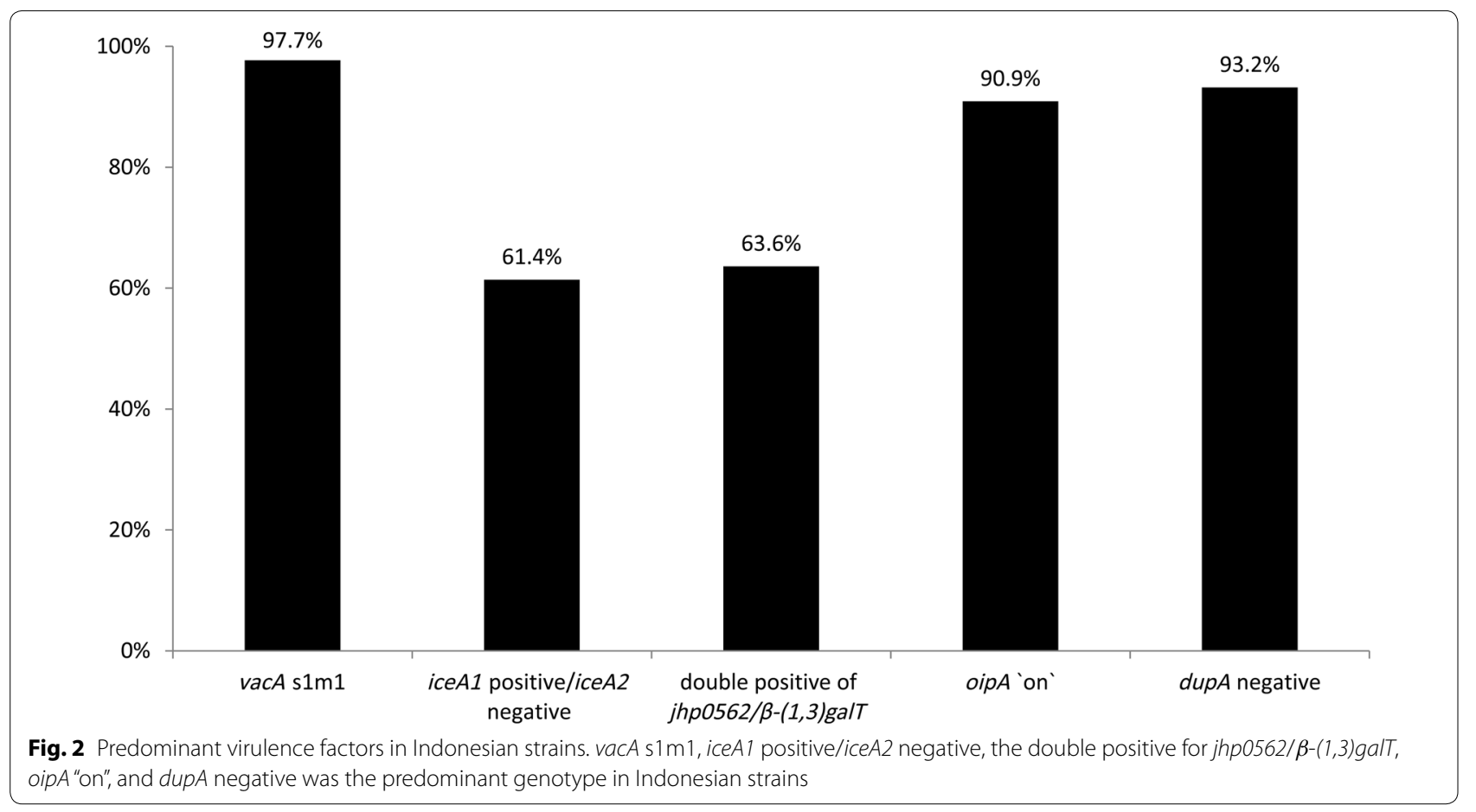


positive test result were considered positive for $H$. pylori infection. Written informed consent was obtained from all participants, and the study protocol was approved by the Ethics Committee of Dr. Cipto Mangunkusumo Teaching Hospital (Jakarta, Indonesia), Dr. Soetomo Teaching Hospital (Surabaya, Indonesia), Dr. Wahidin Sudirohusodo Teaching Hospital (Makassar, Indonesia), and Oita University Faculty of Medicine (Yufu, Japan).

\section{Determination of gastritis stage}

All biopsy materials for histological testing were fixed in $10 \%$ buffered formalin and embedded in paraffin. Serial sections were stained with hematoxylin and eosin as well as May-Giemsa stain. The degree of inflammation, neutrophil activity, atrophy, intestinal metaplasia, and bacterial density were classified into 4 grades according to the updated Sydney system: 0, 'normal'; 1, 'mild'; 2, 'moderate'; and 3, 'marked' [38]. Samples with grade 1 or more atrophy were considered atrophy-positive [39]. Immunohistochemistry was performed as previously described [40]. Briefly, after antigen retrieval and inactivation of endogenous peroxidase activity, tissue sections were incubated with $\alpha-H$. pylori antibody (DAKO, Denmark) overnight at $4{ }^{\circ} \mathrm{C}$. After washing, the sections were incubated with biotinylated goat antirabbit IgG (Nichirei Co., Japan), followed by incubation with an avidin-conjugated horseradish peroxidase solution (Vectastain Elite ABC kit; Vector Laboratories Inc., Burlingame, CA, USA). Peroxidase activity was detected using an $\mathrm{H}_{2} \mathrm{O}_{2}$ /diaminobenzidine substrate solution.

\section{H. pylori isolation and genotyping}

$H$. pylori colonies were cultured from antral biopsy specimens using standard methods [9]. For $H$. pylori culture, 1 antral biopsy specimen was homogenized in saline and inoculated onto Skirrow's medium and incubated for up to 10 days at $37{ }^{\circ} \mathrm{C}$ under microaerophilic conditions $\left(10 \% \mathrm{O}_{2}, 5 \% \mathrm{CO}_{2}\right.$, and $\left.85 \% \mathrm{~N}_{2}\right)$. H. pylori were identified on the basis of colony morphology, Gram staining results, and positive reactions for oxidase, catalase, and urease. Isolated strains were stored at $-80{ }^{\circ} \mathrm{C}$ in Brucella Broth (Difco, NJ, USA) containing $10 \%$ dimethyl sulfoxide and $10 \%$ horse serum. H. pylori DNA was extracted from these colonies for $H$. pylori genotyping using the QIAamp DNA Mini Kit (QIAGEN, Valencia, CA, USA) according to the manufacturer's directions. The list of primers used for the detection of virulence factors of $H$. pylori is shown in Table 5 . The cagA status was determined by polymerase chain reaction (PCR) amplification and direct sequencing of the EPIYA repeat region and the pre-EPIYA region. The oipA status was determined by PCR-based sequencing of the signal region, as

Table 5 The primers used for detecting virulence factors of $\boldsymbol{H}$. pylori

\begin{tabular}{|c|c|c|c|}
\hline Genes & Primer sequences $\left(5^{\prime} \rightarrow 3^{\prime}\right)$ & PCR product (bp) & PCR conditions \\
\hline \multirow[t]{2}{*}{$\operatorname{cagA}$} & ACC CTA GTC GGT AAT GGG & 521 & $94^{\circ} \mathrm{C}, 1 \mathrm{~min} ; 52^{\circ} \mathrm{C}, 1 \mathrm{~min} ; 72^{\circ} \mathrm{C}, 1 \mathrm{~min}$ (35 cycles) \\
\hline & GCTTTA GCTTCT GAY ACY GC & & \\
\hline \multicolumn{3}{|l|}{$\operatorname{vac} A$} & $94^{\circ} \mathrm{C}, 1 \mathrm{~min} ; 52^{\circ} \mathrm{C}, 1 \mathrm{~min} ; 72^{\circ} \mathrm{C}, 1 \mathrm{~min}$ (35 cycles) \\
\hline \multirow[t]{2}{*}{$\mathrm{s} 1 / \mathrm{s} 2$} & ATG GAA ATA CAA CAA ACA CAC & $259 / 268$ & \\
\hline & CTG CTT GAA TGC GCC AAA C & & \\
\hline \multirow[t]{2}{*}{$\mathrm{m} 1 / \mathrm{m} 2$} & CAA TCT GTC CAA TCA AGC GAG & $567 / 642$ & \\
\hline & GCG TCA AAA TAA TTC CAA GG & & \\
\hline \multirow[t]{2}{*}{ oipA } & CCA TGA AAA AAG CTC TCT TAC T & 430 & $94^{\circ} \mathrm{C}, 30 \mathrm{~s} ; 50^{\circ} \mathrm{C}, 30 \mathrm{~s} ; 72^{\circ} \mathrm{C}, 30 \mathrm{~s}$ (25 cycles) \\
\hline & GCC CTT TTA CCC TTC GTT CAA C & & \\
\hline \multicolumn{3}{|l|}{ iceA } & $94^{\circ} \mathrm{C}, 1 \mathrm{~min} ; 56^{\circ} \mathrm{C}, 1 \mathrm{~min} ; 72^{\circ} \mathrm{C}, 1 \mathrm{~min}$ (30 cycles) \\
\hline \multirow[t]{2}{*}{ iceA1 } & GTG TTT TTA ACC AAA GTA TC & 247 & \\
\hline & CTA TAG CCA STYTCTTTG CA & & \\
\hline \multirow[t]{2}{*}{ iceA2 } & GTT GGG TAT ATC ACA ATT TAT & 229 & \\
\hline & TTT CCC TAT TTT CTA GTA GGT & & \\
\hline \multirow[t]{2}{*}{ dupA F2R2 } & ATG TTT CTT GGTTTA GAG GG & 2499 & $95^{\circ} \mathrm{C}, 30 \mathrm{~s} ; 56^{\circ} \mathrm{C}, 30 \mathrm{~s} ; 72^{\circ} \mathrm{C}, 30 \mathrm{~s}$ (35 cycles) \\
\hline & TTA TAC ATA TTG AAT ATT CTC GC & & \\
\hline \multirow[t]{2}{*}{ dupA F5R3 } & GGTTTC TAC TGA CAG AGC GC & 468 & \\
\hline & CGT ATTTAG TCA GTA AGTTGG CG & & \\
\hline \multirow[t]{2}{*}{ jhp0562/ $\beta$-(1,3)galT } & TGA AAA GCC CTT TTG ATT TTG & $301 / 602$ & $95^{\circ} \mathrm{C}, 30 \mathrm{~s} ; 56^{\circ} \mathrm{C}, 30 \mathrm{~s} ; 72^{\circ} \mathrm{C}, 30 \mathrm{~s}$ (35 cycles) \\
\hline & GCT GTA GTG GCC ACA TAC ACG & & \\
\hline
\end{tabular}


described previously $[8,24,41]$. The presence of the $v a c A$ genotype (s1 or $\mathrm{s} 2$, and $\mathrm{m} 1$ or $\mathrm{m} 2$ ), iceA (iceA1 or iceA2), $d u p A$, jhp0562, and $\beta-(1,3)$ galT were determined based on PCR product size, as described previously [22, 42-45]. The amplified fragment was detected by $1.5 \%$ agarose gel electrophoresis. DNA sequencing was performed using a Big Dye Terminator v3.1 Cycle Sequencing Kit and an AB 3130 Genetic Analyzer (Applied Biosystems, Foster City, CA, USA), according to the manufacturer's instructions. Multiple sequence alignments of the cagA pre-EPIYA and cagA were generated using MAFFT version 7 (available at http://mafft.cbrc.jp/alignment/server/) and confirmed by visual inspection.

\section{Statistical analysis}

Data were analyzed using SPSS, version 19 (SPSS Inc., Chicago, IL, USA). Discrete variables were tested using the Chi square test; continuous variables were tested using Mann-Whitney $U$ and $t$-tests. A two-tailed $P$ value $\leq 0.05$ was considered statistically significant.

\begin{abstract}
Abbreviations
PCR: polymerase chain reaction; SHP2: Src homology-2 domain-containing phosphatase 2; L: interleukin; DU: duodenal ulcer; LPS: lipopolysaccharide; Le: lewis; GU: gastric ulcer.
\end{abstract}

\section{Authors' contributions}

MM and YY designed the study; prepared the isolates; acquired, analyzed, and interpreted the data; and wrote the manuscript. AFS contributed to study design and acquired the data. LHZ, Z, FA, WBU, DS, PA, APU acquired data. YAR and PS acquired data and prepared the isolates. TU contributed to data analysis and interpretation. DM, IAN, AFS, N, and YY contributed to manuscript revision for scientific content. All authors read and approved the final manuscript.

\begin{abstract}
Author details
${ }_{1}^{1}$ Department of Environmental and Preventive Medicine, Oita University Faculty of Medicine, Yufu 879-5593, Japan. ${ }^{2}$ Gastroentero-Hepatology Division, Department of Internal Medicine, Airlangga University Faculty of Medicine, Surabaya 60131, Indonesia. ${ }^{3}$ Institute of Tropical Disease, Airlangga University, Surabaya 60115, Indonesia. ${ }^{4}$ Division of Gastroenterology, Department of Internal Medicine, Faculty of Medicine, University of Indonesia, Jakarta 10430, Indonesia. ${ }^{5}$ Division of Gastroentero-Hepatology, Department of Internal Medicine, Faculty of Medicine, University of Sumatera Utara, Medan 20136, Indonesia. ${ }^{6}$ Department of Internal Medicine, Faculty of Medicine, Center of Gastroentero-Hepatology, Hasanuddin University, Makassar 90245, Indonesia. ${ }^{7}$ Department of Internal Medicine, Santo Antonius Hospital, Pontianak 78115, Indonesia. ${ }^{8}$ Department of Internal Medicine, Yowari Hospital, Jayapura 99352, Indonesia. ${ }^{9}$ Department of Molecular Pathology, Oita University Faculty of Medicine, Yufu 879-5593, Japan. ${ }^{10}$ Department of Gastroenterology and Hepatology, Baylor College of Medicine and Michael DeBakey Veterans Affairs Medical Center, Houston, TX 77030, USA.
\end{abstract}

\section{Acknowledgements}

This report is based on work supported in part by grants from the National Institutes of Health (DK62813) (YY), and Grants-in-Aid for Scientific Research from the Ministry of Education, Culture, Sports, Science and Technology (MEXT) of Japan (24406015, 24659200, 25293104, 26640114, 15H02657 and 221S0002) (YY). This work was also supported by the Japan Society for the Promotion of Science (JSPS) Institutional Program for Young Researcher Overseas Visits and the Strategic Funds for the Promotion of Science and Technology from Japan Science and Technology Agency (JST).

\section{Compliance with ethical guidelines}

\section{Competing interests}

The authors declare that they have no competing interests.

Received: 3 July 2015 Accepted: 7 September 2015

Published online: 05 October 2015

\section{References}

1. Kusters JG, van Vliet AH, Kuipers EJ. Pathogenesis of Helicobacter pylori infection. Clin Microbiol Rev. 2006;19(3):449-90.

2. Yamaoka Y. Mechanisms of disease: Helicobacter pylori virulence factors. Nat Rev Gastroenterol Hepatol. 2010;7(11):629-41.

3. Matsuda M, Shiota S, Matsunari O, Watada M, Murakami K, Fujioka T, Yamaoka Y. Prevalence of two homologous genes encoding glycosyltransferases of Helicobacter pylori in the United States and Japan. J Gastroenterol Hepatol. 2011;26(9):1451-6.

4. Higashi H, Tsutsumi R, Fujita A, Yamazaki S, Asaka M, Azuma T, Hatakeyama M. Biological activity of the Helicobacter pylori virulence factor CagA is determined by variation in the tyrosine phosphorylation sites. Proc Natl Acad Sci USA. 2002;99(22):14428-33.

5. Vilaichone RK, Mahachai V, Tumwasorn S, Wu JY, Graham DY, Yamaoka Y. Molecular epidemiology and outcome of Helicobacter pylori infection in Thailand: a cultural cross roads. Helicobacter. 2004;9(5):453-9.

6. Jones KR, Joo YM, Jang S, Yoo YJ, Lee HS, Chung IS, Olsen CH, Whitmire JM, Merrell DS, Cha JH. Polymorphism in the CagA EPIYA motif impacts development of gastric cancer. J Clin Microbiol. 2009;47(4):959-68.

7. Hatakeyama M. Oncogenic mechanisms of the Helicobacter pylori CagA protein. Nat Rev Cancer. 2004;4(9):688-94.

8. Uchida T, Nguyen LT, Takayama A, Okimoto T, Kodama M, Murakami K, Matsuhisa T, Trinh TD, Ta L, Ho DQ, et al. Analysis of virulence factors of Helicobacter pylori isolated from a Vietnamese population. BMC Microbiol. 2009;9:175.

9. Yamaoka Y, Kodama T, Kita M, Imanishi J, Kashima K, Graham D. Relationship of vacA genotypes of Helicobacter pylori to cagA status, cytotoxin production, and clinical outcome. Helicobacter. 1998;3(4):241-53.

10. van Doorn LJ, Figueiredo C, Sanna R, Plaisier A, Schneeberger P, de Boer W, Quint W. Clinical relevance of the cagA, vacA, and iceA status of Helicobacter pylori. Gastroenterology. 1998;115(1):58-66.

11. Yamaoka Y, Kikuchi S, el-Zimaity HM, Gutierrez O, Osato MS, Graham DY. Importance of Helicobacter pylori oipA in clinical presentation, gastric inflammation, and mucosal interleukin 8 production. Gastroenterology. 2002;123(2):414-24.

12. Maeda S, Ogura K, Yoshida H, Kanai F, Ikenoue T, Kato N, Shiratori Y, Omata M. Major virulence factors, VacA and CagA, are commonly positive in Helicobacter pylori isolates in Japan. Gut. 1998;42(3):338-43.

13. Peek RM Jr, Thompson SA, Donahue JP, Tham KT, Atherton JC, Blaser MJ, Miller GG. Adherence to gastric epithelial cells induces expression of a Helicobacter pylori gene, iceA, that is associated with clinical outcome. Proc Assoc Am Physicians. 1998;1 10(6):531-44.

14. Xu Q, Morgan RD, Roberts RJ, Xu SY, van Doorn $\sqcup$, Donahue JP, Miller GG, Blaser MJ. Functional analysis of iceA 7 , a CATG-recognizing restriction endonuclease gene in Helicobacter pylori. Nucleic Acids Res. 2002;30(17):3839-47.

15. Lu H, Hsu PI, Graham DY, Yamaoka Y. Duodenal ulcer promoting gene of Helicobacter pylori. Gastroenterology. 2005;128(4):833-48.

16. Oleastro M, Santos A, Cordeiro R, Nunes B, Megraud F, Menard A. Clinical relevance and diversity of two homologous genes encoding glycosyltransferases in Helicobacter pylori. J Clin Microbiol. 2010;48(8):2885-91.

17. Abdullah AA, Abdullah M, Fauzi A, Syam AF, Simadibrata M, Makmun D. The effectiveness of endoscopic retrograde cholangiopancreatography in the management of patients with jaundice at Cipto Mangunkusumo Hospital, Jakarta. Acta medica Indonesiana. 2012;44(4):298-303.

18. Miftahussurur M, Shiota S, Suzuki R, Matsuda M, Uchida T, Kido Y, Kawamoto F, Maimunah U, Adi P, Rezkitha Y, et al. Identification of Helicobacter pylori infection in symptomatic patients in Surabaya, Indonesia, using five diagnostic tests. Epidemiol Infect. 2015;143(5):986-96.

19. Miftahussurur M, Tuda J, Suzuki R, Kido Y, Kawamoto F, Matsuda M, Tantular IS, Pusarawati S, Nasronudin, Harijanto PN, et al. Extremely low 
Helicobacter pylori prevalence in North Sulawesi, Indonesia and identification of a Maori-tribe type strain: a cross sectional study. Gut pathogens. 2014;6(1):42.

20. Xia Y, Yamaoka Y, Zhu Q, Matha I, Gao X. A comprehensive sequence and disease correlation analyses for the C-terminal region of CagA protein of Helicobacter pylori. PLoS One. 2009;4(11):e7736.

21. Matsunari O, Shiota S, Suzuki R, Watada M, Kinjo N, Murakami K, Fujioka T, Kinjo F, Yamaoka Y. Association between Helicobacter pylori virulence factors and gastroduodenal diseases in Okinawa, Japan. J Clin Microbiol. 2012;50(3):876-83.

22. Takahashi A, Shiota S, Matsunari O, Watada M, Suzuki R, Nakachi S, Kinjo $N$, Kinjo F, Yamaoka Y. Intact long-type dupA as a marker for gastroduodenal diseases in Okinawan subpopulation, Japan. Helicobacter. 2013;18(1):66-72.

23. Vilaichone RK, Mahachai V, Tumwasorn S, Wu JY, Graham DY, Yamaoka Y. Molecular epidemiology and outcome of Helicobacter pylori infection in Thailand: a cultural cross roads. Helicobacter. 2004;9(5):453-9.

24. Yamaoka Y, Kato M, Asaka M. Geographic differences in gastric cancer incidence can be explained by differences between Helicobacter pylori strains. Intern Med. 2008;47(12):1077-83.

25. Utsumi T, Lusida MI, Yano Y, Nugrahaputra VE, Amin M, Juniastuti, Soetjipto, Hayashi $\mathrm{Y}$, Hotta $\mathrm{H}$. Complete genome sequence and phylogenetic relatedness of hepatitis B virus isolates in Papua, Indonesia. J Clin Microbiol. 2009;47(6):1842-7.

26. Olbermann P, Josenhans C, Moodley Y, Uhr M, Stamer C, Vauterin M, Suerbaum S, Achtman M, Linz B. A global overview of the genetic and functional diversity in the Helicobacter pylori cag pathogenicity island. PLoS Genet. 2010;6(8):e1001069.

27. Zhang XS, Tegtmeyer N, Traube L, Jindal S, Perez-Perez G, Sticht H, Backert $\mathrm{S}$, Blaser MJ. A specific A/T polymorphism in Western tyrosine phosphorylation B-motifs regulates Helicobacter pylori CagA epithelial cell interactions. PLoS Pathog. 2015;11(2):e1004621.

28. Uemura N, Okamoto S, Yamamoto S, Matsumura N, Yamaguchi S, Yamakido M, Taniyama K, Sasaki N, Schlemper RJ. Helicobacter pylori infection and the development of gastric cancer. N. Engl J Med. 2001;345(11):784-9.

29. Hansson LE, Nyren O, Hsing AW, Bergstrom R, Josefsson S, Chow WH, Fraumeni JF Jr, Adami HO. The risk of stomach cancer in patients with gastric or duodenal ulcer disease. N. Engl J Med. 1996;335(4):242-9.

30. Chomvarin C, Namwat W, Chaicumpar K, Mairiang P, Sangchan A, Sripa B, Tor-Udom S, Vilaichone RK. Prevalence of Helicobacter pylori vacA, cagA, cagE, iceA and babA2 genotypes in Thai dyspeptic patients. Int J Infect Dis. 2008;12(1):30-6.

31. Rahman M, Mukhopadhyay AK, Nahar S, Datta S, Ahmad MM, Sarker S, Masud IM, Engstrand L, Albert MJ, Nair GB, et al. DNA-level characterization of Helicobacter pylori strains from patients with overt disease and with benign infections in Bangladesh. J Clin Microbiol. 2003;41(5):2008-14.

32. Appelmelk BJ, Vandenbroucke-Grauls CM. H pylori and Lewis antigens Gut. 2000;47(1):10-1.
33. Heneghan MA, McCarthy CF, Moran AP. Relationship of blood group determinants on Helicobacter pylori lipopolysaccharide with host lewis phenotype and inflammatory response. Infect Immun. 2000;68(2):937-41.

34. Schmidt HM, Andres S, Kaakoush NO, Engstrand L, Eriksson L, Goh KL, Fock KM, Hilmi I, Dhamodaran S, Forman D, et al. The prevalence of the duodenal ulcer promoting gene (dupA) in Helicobacter pylori isolates varies by ethnic group and is not universally associated with disease development: a case-control study. Gut pathogens. 2009;1(1):5.

35. Shiota S, Watada M, Matsunari O, Iwatani S, Suzuki R, Yamaoka Y. Helicobacter pylori iceA, clinical outcomes, and correlation with cagA: a metaanalysis. PLoS One. 2012;7(1):e30354.

36. Malfertheiner P, Megraud F, O'Morain CA, Atherton J, Axon AT, Bazzoli F, Gensini GF, Gisbert JP, Graham DY, Rokkas T, et al. Management of Helicobacter pylori infection-the Maastricht IV/Florence Consensus Report. Gut. 2012;61(5):646-64.

37. Shiota S, Suzuki R, Yamaoka Y. The significance of virulence factors in Helicobacter pylori. J Dig Dis 2013.

38. Dixon M, Genta R, Yardley J, Correa P. Classification and grading of gastritis. The updated Sydney System. International Workshop on the Histopathology of Gastritis, Houston 1994. Am J Surg Pathol. 1996;20(10):1161-81.

39. Bornschein J, Selgrad M, Wex T, Kuester D, Malfertheiner P. Serological assessment of gastric mucosal atrophy in gastric cancer. BMC Gastroenterol. 2012;12:10.

40. Uchida T, Kanada R, Tsukamoto Y, Hijiya N, Matsuura K, Yano S, Yokoyama S, Kishida T, Kodama M, Murakami K, et al. Immunohistochemical diagnosis of the cagA-gene genotype of Helicobacter pylori with anti-East Asian CagA-specific antibody. Cancer Sci. 2007;98(4):521-8.

41. Yamaoka Y, Kikuchi S, el-Zimaity H, Gutierrez O, Osato M, Graham D. Importance of Helicobacter pylori oipA in clinical presentation, gastric inflammation, and mucosal interleukin 8 production. Gastroenterology. 2002;123(2):414-24.

42. Oleastro M, Monteiro L, Lehours P, Mégraud F, Ménard A. Identification of markers for Helicobacter pylori strains isolated from children with peptic ulcer disease by suppressive subtractive hybridization. Infect Immun. 2006;74(7):4064-74

43. Atherton JC, Cao P, Peek RM Jr, Tummuru MK, Blaser MJ, Cover TL. Mosaicism in vacuolating cytotoxin alleles of Helicobacter pylori. Association of specific vacA types with cytotoxin production and peptic ulceration. J Biol Chem. 1995;270(30):17771-7.

44. Yamaoka Y, El-Zimaity H, Gutierrez O, Figura N, Kim J, Kodama T, Kashima K, Graham D, Kim J. Relationship between the cagA 3' repeat region of Helicobacter pylori, gastric histology, and susceptibility to low pH. Gastroenterology. 1999;117(2):342-9.

45. Yamaoka Y, Kodama T, Gutierrez O, Kim JG, Kashima K, Graham DY. Relationship between Helicobacter pylori iceA, cagA, and vacA status and clinical outcome: studies in four different countries. J Clin Microbiol. 1999;37(7):2274-9.

\section{Submit your next manuscript to BioMed Central and take full advantage of:}

- Convenient online submission

- Thorough peer review

- No space constraints or color figure charges

- Immediate publication on acceptance

- Inclusion in PubMed, CAS, Scopus and Google Scholar

- Research which is freely available for redistribution

Submit your manuscript at

www.biomedcentral.com/submit
C Biomed Central 